\title{
Strategic Analysis of Export Activities of Enterprises to Ensure Sustainable Development
}

\author{
By Elina Pakhucha ${ }^{1}$, Natalia Babko ${ }^{2}$, Tamila Bilousko ${ }^{3}$, Roman Bilousko ${ }^{3}$, \\ Serhiy Vynohradenko ${ }^{3}$, Otabeg Azizov ${ }^{2}$
}

\begin{abstract}
In the article necessity and significance to study of financial risks, which are a constant factor in the activity of any enterprise, are substantiated. It is established that for a broader understanding of the essence of financial risk it is necessary to consider it as a cumulative risk of the enterprise. The growing impact of financial risks on the results of financial and economic activities is associated with the uncertain economic situation, the instability of financial market conditions, the rapid introduction of new financial technologies and financial instruments, expanding the scope of financial relations of the enterprise. Methods of financial risk assessment are investigated, which involve the identification of risks, determining the causes of their occurrence and potential risk areas, as well as the negative consequences of making a risky decision or possible benefits. Comparing the methods of quantitative assessment of financial risk, it was found that the level of risk may vary depending on the chosen method of assessment. A system of financial ratios has been formed to quantify the risk of enterprises of different sizes, namely for large, medium and small enterprises, which most accurately reflect the current financial situation. An assessment of the financial results of enterprises operating in the field of wholesale trade. The financial results before the taxation of activity as an indicator that characterizes the potential for profit generation of wholesale trade enterprises by size distribution are studied. The value of financial results (balance) before taxation of wholesale trade enterprises is forecasted. It is established that the growing pressure of the crisis and insecurity on the part of the state will lead to the transition from the crisis in which enterprises are today, to a state of economic bankruptcy. This situation requires the formation and use of financial resources of enterprises, based on the system and complexity of making and implementing management decisions. Quantitative and qualitative assessment of financial risks of wholesale trade enterprises belonging to groups of large, medium and small enterprises was carried out. Based on these calculations, the ranking of priorities in the management of financial stability. It is established that the first place among the blocks of financial coefficients of risk assessment of enterprises is occupied by the block of business activity, then the block of profitability indicators, the block of liquidity indicators, the final block of capital structure. For each of the defined blocks the directions of increase, or optimization that will provide financial stability of the enterprise are presented.
\end{abstract}

Keywords: financial risk, financial stability, financial risk minimization, profitability, trade enterprises

\section{Introduction}

Regardless the activity in national economy sector, modern producers face a competitive struggle in the context of globalization. Modern agricultural entrepreneurs take part in the competitive struggle for the consumer under the conditions of a changing

\footnotetext{
${ }^{1}$ Kharkiv National University of Internal Affairs, Ukraine

${ }^{2}$ Kharkiv Petro Vasylenko National Technical University of Agriculture, Ukraine

${ }^{3}$ Kharkiv National Agrarian University named after V. V. Dokuchaiev, Ukraine

${ }^{*}$ Corresponding Author
} 
environment. They become more and more dependent on using a number of advantages over competitors to survive in the competitive struggle.

Modern changes in the main aspects of competition and specific nature of agricultural production have accelerated the agricultural market globalization and increased aggression in every sector. Under these conditions, most agricultural producers were not ready to manage their business efficiently and change the macroenvironment regularly and rapidly. To be competitive, they needed to improve product quality, minimize production and sales costs, and improve methods and techniques of production management and organization of work.

At the same time, further changes in land ownership in the agricultural sector resulted to a conflict of interest between the agricultural producers and the state, thereby decreasing the competitiveness of agricultural producers.

In Ukraine, the agricultural sector has potential and highest priority because it ensures the country's food security. However, to manage the agricultural production efficiently, it is of paramount importance to address the issue of efficient output of competitive products by agricultural enterprises.

These enterprises must respond promptly to changes in their environment, which exposes to risk their good performance and market standing.

In modern conditions, agricultural producers need to take into account and predict possible changes faster than their competitors. First of all, the prompt response to changes is related to the capabilities of enterprises to implement the corporate development plan. Besides, this plan includes procedures for choosing strategic growth priorities, defining main goals and objectives intended to take advantage of the best option of production and sales and rationally use the resource potential.

In the context of market globalization, the main challenge for agricultural enterprises is to attract potential investors. Really, the agricultural sector does not seem attractive to potential investors. This is due to a long payback period, solid investments and a great number of uncontrolled factors influencing the results of investment project. The investor primarily intends to obtain economic benefits from the investments in agricultural production development. The most investment attractive enterprises are companies which ensure payback, output expansion and return of investments. To the investor, the main indicators of interest are solvency, financial stability and rate of return, which directly reflect the production and economic activities of enterprises. In effect, the enterprises having a clear corporate development plan are attractive for investment.

To ensure sustainable development in context of globalization and improve market standing, enterprises must prioritize the ways of ensuring their competitiveness, namely: development of a sound and optimum production program in accordance with market requirements and consumer needs, taking into account their capabilities and resource potential; cooperation of agricultural enterprises; integration deepening; implementation of a corporate development plan with due regard to the specific nature of their activities and competitors' experience. This will result in a stable competitive position in the market. To achieve a high level of competitiveness, it is necessary to enable the sustainable development of enterprises. One of the factors having an impact on the competitiveness of production facilities is an efficient production of competitive products. Therefore, it is necessary to address the issue of achieving a higher level of product competitiveness, 
which affects the level of overall competitiveness of agricultural enterprises.

\section{Literature Review and Problem Statement}

As noted by the authors of the research paper (Sieradzka \&Luft, 2015), enterprise competitiveness is a multidimensional and relative concept without a universal and approved definition. Consequently, there are quite a lot of different definitions, but the most often competitiveness is understood as an ability to compete. A competitive enterprise is flexible and able to adapt to environment changes if this gives any profit. Modern theories of enterprise competitiveness emphasize the employees' potential, available knowledge and skills ensuring a stable competitive advantage in the market, having universal resources that are difficult to imitate and without analogues in the market. The research paper (Bojko \& Bojko, 2019) investigates the modern view of competitiveness of agricultural enterprises. It specifies the indicators affecting competitiveness of agricultural enterprises. It considers the external and internal factors for the assessment of competitiveness of agricultural enterprises. It identifies current challenges to their competitiveness.

The study (Leśniewski, 2018) provides an overview of competitiveness problem. The research hypothesis was formulated as follows: competitiveness is an abstract notion that is the basis for an enterprise operation in a competitive market. The study used the method of interpretation of scientific literature, as well as logical reasoning and common sense as a part of this method. The study confirms the importance of competitiveness for an organization working in a changing environment.

The study (Zosj-Kior, Ghermanenko, \& Sobakar, 2018) is devoted to modern aspects of competitiveness management. It generalizes the notion, characterizing the enterprise competitiveness. It considers the hierarchy of factors for achieving competitiveness. It justifies the need for an efficient competitiveness management system to be created at enterprises on the basis of available production, financial, intellectual and labor resources. The article (Ian, 2017) considers the competitiveness of markets for agricultural products and raw materials. The biggest takeaway is that there is insufficient empirical evidence for food businesses that gives power to the buyer, and there are limited data on vertical contracts between the food industry and agriculture. Besides, there is little evidence of food retail behavior and vertical coordination between retail food products and agroprocessing facilities.

The article (Pakhucha, 2020) emphasizes the importance of coordination of marketing and communication activities to successfully execute the chosen marketing strategy. It specifies the role of low-budget marketing communications, including but not limited to enabling small and medium-sized businesses to improve their marketing activities and use additional tools for the purpose of achieving competitiveness. It lists the basic low-budget marketing communication technologies which are now used by enterprises. It has been noted that the use of Internet marketing tools also allows saving money and expanding enterprise activities, primarily due to shifting away from the local market to the national and international market.

The authors of the paper (Shevchenko, Kokuytseva, \& Ovchinnikova, 2019) have generalized the approach of comparison the competitiveness of enterprises working in 
particular segments of the global market. Their approach consists in giving prominence to a group of key competitiveness indicators, determining their current and expected values, forming a Pareto set (in the set of selected enterprises) and identifying leaders in this Pareto set according to the values of generalizing criteria.

The paper (Sievidova, 2018) analyzes the advantages and disadvantages of modern methods of enterprise competitiveness assessment; these methods can be specific or universal depending on methodological principles applied.

The article (Ivanova, Varyanichenko, Sannikova, \& Faizova, 2018) investigates the special aspects of enterprise competitiveness assessment using an integrated indicator. It has proved that enterprise competitiveness includes competitiveness of three main economic activities, i. e. supply, production and sales. It justifies that the integrated competitiveness indicator must include the indicators of production, financial standing, deployment of staff, degree of innovation, etc. It offers a method for enterprise competitiveness assessment, which is universal and easy to use.

The study (Brych \& Okhota, 2019) reveals the issue of achieving global competitiveness in the context of globalization. It considers the theoretical and methodical basis for achieving global competitiveness, as well as revealed and analyzed current trends in global competitiveness. Much attention is paid to the priority of improving global competitiveness with due regard to regional problems.

The article (Dughijenko \& Symonenko, 2015) investigates the basic tendencies and factors of development of the Ukrainian agricultural sector, current state and problems of agricultural industry in Ukraine. It analyzes the level of competitiveness of domestic agricultural facilities in world markets and offers the ways of improving competitiveness of domestic enterprises in world agricultural markets.

As it is stated in (Kamila, 2017), to stay in business, the companies must forecast and accurately assess the situation, adopt effective measures, never stop to develop in a changing environment and make structural changes. These determinants are essential not only for companies' survival and restoration of equilibrium in the unstable environment, but also for the elaboration of dynamic plans to ensure companies' smooth and efficient work, competitive advantages and further development.

The article (Kasych \& Ghlushhenko, 2016) considers the efforts of scientists analyzing the concept of "enterprise competitiveness management" in their papers, provides the main approaches to its interpretation, as well as its own definition of this notion. It justifies the use of a systematic approach to enterprise competitiveness management. It considers the competitiveness management system as a whole and its main subjects, their tasks, objects of management in particular. It investigates the basic methods of competitiveness management.

The paper (Patyka, 2018) offers an improved set of priorities to ensure the Ukrainian agriculture competitiveness in world markets and classifies these priorities into two main categories: market-oriented and production-oriented. It has proved that the strategy of Ukrainian goods promotion in world markets must be moderately aggressive and sometimes aggressive, a set of competitiveness priorities is to be implemented to strengthen the position of Ukraine's agriculture in world markets.

The study (Stawasz, 2019) dwells on the ability to gain business knowledge which determines the level of small enterprise competitiveness and the efficiency of use of this 
external business knowledge. The study has validated the hypothesis about a significant impact of business consulting on the system of competitiveness determinants. It has also validated the hypothesis about the positive indirect correlation between business advice, ability of enterprises to acquire business knowledge and their competitiveness.

The study (Yamova, at al., 2018) tests one of the methods of assessment and emphasizes the possibility of adequate competitiveness assessment in the realities of modern industrial economy. It comes to the conclusion that in future the competitiveness assessment will require adding new factors to the integrated indicators to keep up the pace of industrial economy growth. These factors contribute to the innovation and research potential, being a key component for the development of leading sectors of economy.

The article (Kuzmenko, 2018) establishes strategic directions for improving enterprise competitiveness; they must be defined from a perspective of customer-oriented paradigm of modern enterprises' innovative development methods; they must be simple in their strategic tools and be essential in logical tools of modern management that is a driving force in the competitiveness management system and ensure competitiveness and longterm profitability. It is advisable to choose the strategic directions, which improve competitiveness by means of ensuring compliance of the stages of enterprise growth with the enterprise's type of strategy, using multidimensional space.

The paper (Ghranovsjka, 2017) investigates the institutional mechanism of agricultural enterprise competitiveness and its efficiency in the national environment. It has worked out a model of competitive development of agricultural enterprises, which includes establishing a system of institutional support for the agricultural enterprise development and an ordered set of formal and informal institutions that determine and regulate the territorial, social, production, economic, environmental, regulatory and organizational parameters of this development.

The paper (Pakhucha, 2018) has investigated the factors influencing agricultural enterprise competitiveness, which are divided into internal and external factors and further subdivided into the factors of different levels depending on the degree of control exercised by the state and the enterprise itself. The study of the components of external and internal factors influencing enterprise competitiveness has shown that in each specific case a particular enterprise needs a comprehensive study and consideration of each component to identify the enterprise's strengths and weaknesses.

Using solid modeling, the study (Da Huo, at al, 2020) has found out that competitive labor costs, foreign direct investment and export options are important factors for the further development of export competitiveness of agricultural enterprises from emerging markets. It has discovered that the emerging markets with a higher level of competitiveness may principally concentrate in clusters with a lower level, if export is concerned. The results of this study may help in dealing with the impact of geographical economic factors on the export competitiveness of agricultural enterprises from emerging markets.

The authors of research paper (Ljashevsjka, Skvira, \& Bojko, 2018) identify the factors that can improve competitiveness of Ukrainian agricultural enterprises in the foreign market. They further compare the agricultural enterprises with a different competitiveness development potential. They also consider the factors reducing competitiveness. They focus on building and improving competitiveness of agricultural enterprises in the world economic area. 
The article (Pakhucha, 2020) investigates the marketing factors that affect the level of agricultural enterprise competitiveness. It determines the main tasks of marketing communications, including the important tasks of optimizing chances to improve the image, ensuring compliance with the data provided on the product brand, design and style standards, and efficiently taking advantage of marketing and sponsor offers.

Under the conditions of rapid development of Ukraine's agribusiness, the improved competitiveness of domestic enterprises is becoming increasingly important. The article (Boghomolova, 2019) considers scientific approaches to the concepts of "competition", "competitiveness" and "agricultural enterprise competitiveness". It analyzes the main factors influencing agricultural enterprise competitiveness under the conditions of a changing market environment and recession; it identifies the structural components of improved competitiveness of agricultural enterprises and suggests the ways of refining them.

To improve the resource-based strategy and ensure its competitiveness, the research paper (Radev, at al., 2020) suggests as follows: a ready-made algorithm for the elaboration of enterprise resource-based strategy; systematized and generalized portfolio of enterprise resource-based strategies for the main groups of resources; recommendations for the application of improved methods of assessing the enterprise resource potential as to its impact on competitiveness using the balanced score card.

The article (Skrynkovskyy, at al., 2018) determines the key parameters of graphical assessment of enterprise competitiveness: operational efficiency of an enterprise (financial, economic, industrial, commercial aspects); competitiveness of its products; market concentration for this enterprise; personnel quality and level of personnel management; efficiency of information technology application in the enterprise management.

Despite a significant contribution to the study of this problem, it should be noted that some aspects remain understudied. In the light of globalization of agricultural markets we need a more thorough study of current competitiveness and its development trends. The study involves the investigation of the best algorithm for measuring enterprise competitiveness and assessing the general situation with due regard to the market globalization. In the contemporary context, market globalization monitoring is an important tool to reduce or negate the negative impact of a changing environment and ensure sustainable development of enterprises.

The purpose and objectives of the study are to determine the position of enterprises in the global agricultural market by means of assessing their competitiveness in the context of globalization. To achieve this purpose, we set the following objectives: to determine the methods of assessing enterprise competitiveness in the agricultural market, improve the product competitiveness assessment at different stages, assess current enterprise competitiveness in the global agricultural market, identify priorities for gaining competitive advantages in the domestic agricultural market.

\section{Specific Aspects of Determining Enterprise Competitiveness in the Agricultural Market}

In the course of globalization changes, the economy has turned into an integral multi layered system with dissymmetrically developed elements due to the difference 
between the available and hidden potential. These changes set new challenges, namely ensuring the unimpaired performance of national economies and their main sectors in the long run and minimization of the impact of economic, political, social and environmental risks.

The main element of the global economic system is the global market and its structural segments. In the context of globalization, the agricultural markets are important for businesses, the influence of external competitive environment is also increasing, and the global interdependence of sectors of national economies creates new conditions for the development of countries.

The structural transformation of foreign economic potential aimed at the export of competitive agricultural products is becoming a new direction of improving business competitiveness in the context of globalization.

The methodological tools for the general assessment of competitive advantages of agricultural sector entities and facilities are a structural element of the general concept. Currently, there are no universal methods of assessment of competitiveness and competitive advantage in economic theory and practice; it is the result of differences in specialization, technological structure, financial, economic and legal status, strategic orientation and level of integration into the global economic area. This situation complicates the development of general assessment methods to compare domestic and foreign competitors, say nothing about the inconsistency of the world and domestic system of accounting and statistical reporting.

Quite a lot of research papers are devoted to measuring competitive advantages. Noteworthy is the approach described in the paper (Zakrevsjka, 2004) which classifies methodological approaches into the following groups: groups based on the theory of enterprise and industry equilibrium and production factor theory; groups based on the effective competition theory; groups based on the interrelation between the level of enterprise competitiveness and product quality indicators; structural groups where the enterprise chooses its market position according to the level of industry monopolization; functional groups determining the ratio of costs, prices, capacity utilization, output, rate of return, etc.; groups assessing enterprise competitiveness according to the product quality; groups using matrices to assess enterprise competitiveness.

The most common methods to characterize the enterprise's (product's) market position are divided into formal and matrix models for studying a particular business activity. According to (Kyrychenko \& Mighdaljsjkyj, 2017), among the formal methods a special mention should be made of M. Porter's model, product-market model (I. Ansoff); accumulated experience model, PLC (product life cycle) model, TLC (technology life cycle) model. The matrix methods include BCG model, McKinsey method, Shell/DPM model, Hofer/Schendel model, ADL method, PIMS method.

The methods characterizing the level of enterprise management include SWOT method (comprehensive strategic analysis), SPACE method (comprehensive strategic analysis); LOTS method; expert assessment method; method of strategic group mapping. The methods characterizing the level of financial and economic activities of enterprises include methods of financial and economic analysis and methods of forecasting the financial standing of enterprises.

To assess competitiveness, foreign scientists use the Relative Export Advantage (RXA) 
Index, Relative Import Penetration Index (RMP), and Relative Trade Advantage Index (RTA) (Sukach, 2015). The first index is defined as the ratio of a country's share in the world exports of a certain type of product to its share in the world exports of all other goods. It should be noted that to calculate this indicator, the world exports of goods are defined as the sum of exports of all countries except those of the country under study. Thus we avoid double counting, when the country's exports (goods) are both a numerator and a component of denominator. Such a calculation is particularly appropriate if the product under study makes up a significant share of world exports or the country has a significant share in the world trade. If the value of this index is more than 1 , the country has comparative competitive advantages in exporting the product under study, if it is less than 1 , it means competitive disadvantages.

To obtain the relative import penetration index, the ratio of import to RMP index is calculated; if it is more than 1, the dependence on imports is high, if is less than 1, the dependence on imports is low.

To calculate the relative trade advantage index, both exports and imports of a certain product are measured. The positive value of this indicator implies comparative competitive advantages of this product in the foreign trade, and the negative value indicates certain competitive disadvantages.

In the light of intra-industry trade growth, the use of both export and import values when assessing competitiveness is becoming increasingly important. If import values are also used, RTA index is a much more exacter and much more informative value of competitiveness (Kvasha \& Gholomsha, 2006).

As it was shown by the study (Skrynkovskyy, 2015), the key parameters for the diagnosis of enterprise product competitiveness are economic $(E)$, market $(M)$ and technical $(T)$ parameters. Therefore, the cumulative indicator of enterprise product competitiveness $\left(I_{E P C}\right)$ is calculated according to the formula:

$$
I_{E P C}=f(E ; P ; T)
$$

To assess enterprise product competitiveness and calculate the cumulative indicator, the expert assessment method is applied, i. e. the experts assess the key parameters, namely economic, market and technical parameters. If the value of IEPC is less than 0.4 , it shows a low level of enterprise product competitiveness. If the index value is in the range of 0.40.8 , the level of product competitiveness is average, if it is in the range of 0.9-1, the level is high.

The product consumption price is the key business indicator to diagnose competitiveness according to the economic parameters $(E)$. The product consumption price $\left(P_{P C}\right)$ is calculated according to the formula:

$$
P_{P C}=C_{P}+C_{U S E} \text {, }
$$

where $C_{P}$ is consumer costs for the purchase of products;

$C_{U S E}$ is consumer costs for the use of products.

The product's market share (PS) is a business indicator from among the market parameters (M) for the diagnosis of enterprise product competitiveness. It is calculated according to the formula: 
$P S=\frac{S_{E P}}{M C_{T}}$,

where $S_{E \mathrm{P}}$ is sales of the enterprise products;

$M C_{T}$ is the total market capacity for the products concerned.

The product quality index $(Q I)$ is a business indicator from among the technical parameters for the diagnosis of enterprise product competitiveness $(T)$. It is calculated according to the formula:

$Q I=f\left(X_{1} ; X_{2} ; X_{3} ; X_{4} ; X_{5}\right)$,

where $X_{1}$ is a level of consumer product safety;

$X_{2}$ is a level of consumer product reliability;

$X_{3}$ is a level of consumer product standardization and unification;

$X_{4}$ is a level of product's environmental friendliness;

$X_{5}$ is a level of efficiency of consumer product use.

Values $X_{1} ; X_{2} ; X_{3} ; X_{4}$ and $X_{5}$ are in the range from 0 to 10 and are calculated by experts during the analysis.

To study agricultural enterprise competitiveness, the cumulative indicator of competitiveness is calculated on the basis of the analysis of potential and current competitiveness (Zbarsjkyj \& Misevych, 2009) according to the formula:

$C_{E}=\sqrt{C_{P} \times R \times R T}$,

where $C_{E}$ is the index of competitiveness of an enterprise of industrialized agriculture;

$C_{P}$ is the index of product competitiveness, calculated as the ratio of the cumulative index of product quality to the product selling price;

$R T$ is the index of enterprise product marketability;

$R$ is the rating index of potential competitiveness.

The rating index of potential competitiveness is calculated according to the formula:

$R=\sqrt{\left(1-a_{1}\right)^{2}+\left(1-a_{2}\right)^{2}+\ldots+\left(1-a_{n}\right)^{2}}$,

where $a_{1}, a_{2}, \ldots a_{n}$ there are indicators of potential competitiveness, namely agricultural land productivity, power supply, power supply per production unit, number of employees, capital-labor ratio, capital-area ratio, labor productivity, production losses, gross output level, level of profitability of production and sales.

To determine the level of agricultural enterprise competitiveness, it is necessary to use methods enabling both to obtain indicators in numerical terms on the basis of specific reliable information and conduct expert assessments with due regard to the specific aspects of agricultural production and product quality (Krjuchkova, 2016).

The algorithm for product competitiveness diagnosis which is a system managing the main stages and parameters is essential for the determination of agricultural product competitiveness in the domestic and foreign markets. The procedure for product competitiveness diagnosis must include the key aspects shown in Fig. 1. 


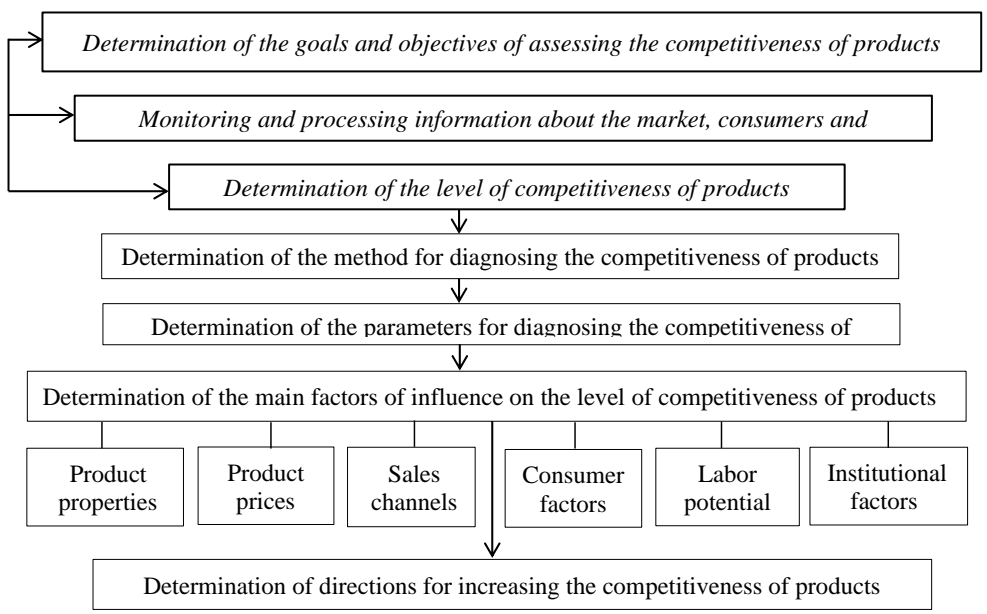

Fig. 1. Stages of the product competitiveness diagnosis

The algorithm shows that agricultural product competitiveness is determined by the level of economic, technical, regulatory, ecological and market parameters of agricultural products which enables them to compete with similar foreign and domestic products. The products are considered to be competitive if their properties comply with the specifications, quality characteristics and international standards. The economic criteria (low export prices, in particular) are essential to competitiveness of domestic agricultural products in the global market. At the same time, the exporters partially use technological and regulatory parameters and predominantly avoid using ecological and marketing parameters to ensure competitive advantages of Ukrainian agricultural products in the global market. It is going to reduce the efficiency, flexibility and stability of foreign economic activities in future.

\section{Determination of Enterprise Competitiveness in the Agricultural Market in the Context of Globalization}

Competitiveness implies a favorable enterprise positioning under market relations, which is of paramount importance to take a stronger competitive position than that of competitors. Actually, having a competitive advantage means that a particular enterprise does something better than its competitors.

Thus, the competitive advantage is the result of the enterprise's actions and its position in the market environment for a certain period of time. Depending on the time period, it is classified into sustainable and temporary competitive advantages. The sustainable advantage is related to the enterprise's stable position in the market, established range of products and invariable competition instruments. The temporary advantage means that the enterprise gains a competitive advantage because of a changing environment and sources of advantages copied by competitors.

Besides, the basic criteria are used for classification of competitive advantages; they are subdivided into three types based on cost leadership, differentiation and concentration. 
The competitive advantage attributed to cost leadership makes the enterprise a leader in the sector of total costs. As a rule, the enterprise bears minimum costs compared to its competitors, still preserving the quality of its products. As to competitiveness attributed to differentiation, it implies identifying products, which are important to consumers and different from the products offered by competitors, though sometimes of a higher pricing tier. The strategic objectives of enterprises do not include levels of costs, but it is impossible not to take them into account. Both cost management strategy and differentiation are intended to give a competitive advantage in a wide range of market segments. The advantage attributed to concentration means that the enterprise focuses on a specific segment that enables to meet customers' requirements.

Ukraine's position in the global food market is determined by quantity, quality and value of exported products. To have a steady income from the export of agricultural products and raw materials, one needs to constantly analyze the development of agrifood markets and systematically and efficiently assess competitiveness of export product groups in the international market. Under these conditions, it is necessary to pay sufficient attention to the diagnosis of competitiveness of domestic agricultural products in the foreign market (Stepasyuk \& Titenko, 2020).

The agricultural products are given the world's most prestigious awards for their quality. The global demand for agricultural products is constantly growing, and the positive moment is availability of gaps in the agrifood segment of global market. However, reducing trade barriers has intensified competition in the international agricultural market. Therefore, to ensure the country's food security, the share of domestic products in food consumption should not be lower than $70 \%$, and at least $80-85 \%$ of domestic products should be competitive compared to imported products. The problem of competitiveness of domestic agricultural products is one of the most serious and urgent problems in the agricultural sector of Ukraine's economy.

Ukraine has integrated into the global market and now it offers eight items from among global agrifood products, though most of them are raw materials, as suggested by the data provided (Fig. 2).

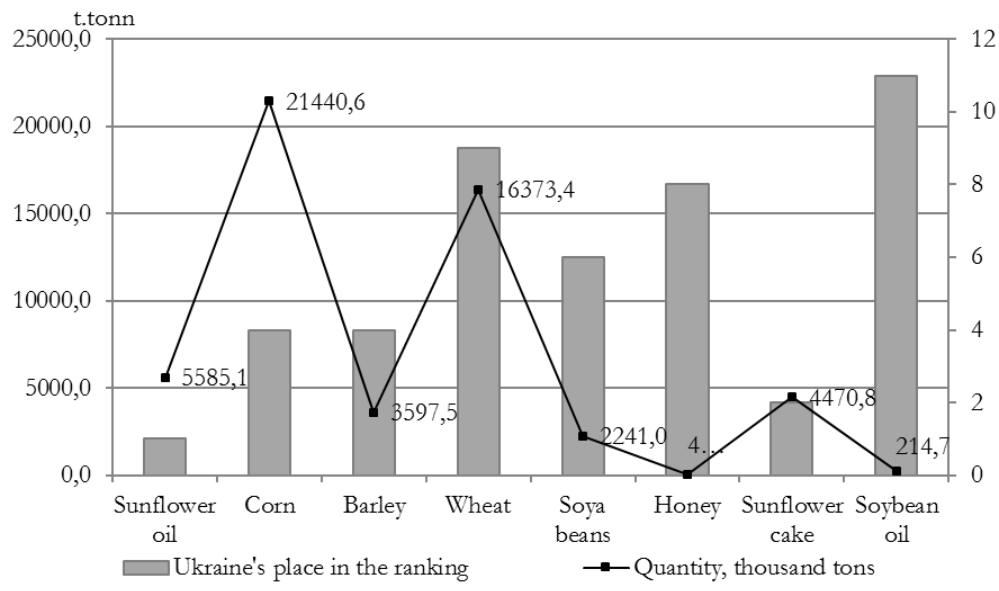

Fig. 2. Ukraine's position in the global market among agricultural producers, 2019. 
In the context of agrifood market globalization and need for global agrifood products, both existing and potential agricultural sectors deserve special attention; the grain industry is one of these sectors since Ukraine is a leading producer of wheat and sunflower (Official website FAOSTAT, 2021).

The main crops due to which Ukraine has become one of the world leaders are cereals and forage crops, including wheat, corn, barley, sunflower, sugar beet, tobacco, legumes, fruit and vegetables. In 2019, the average grain yield increased by $2.2 \mathrm{dt} / \mathrm{ha}$; in 2018, it was 47.4 $\mathrm{dt} / \mathrm{ha}$, and in 2019 , the yield of $49.1 \mathrm{dt} / \mathrm{ha}$ was reached. The yields of some other crops have also increased noteworthily: winter wheat $-41.7 \mathrm{dt} / \mathrm{ha}$, barley - $34.8 \mathrm{dt} / \mathrm{ha}$, corn $71.4 \mathrm{dt} / \mathrm{ha}$, buckwheat - $13.3 \mathrm{c} \mathrm{dt} / \mathrm{ha}$, millet - $18.1 \mathrm{dt} / \mathrm{ha}$, sunflower - $25.1 \mathrm{dt} / \mathrm{ha}$, soybeans - $23.5 \mathrm{dt} / \mathrm{ha}$.

In 2019, agriculture dominated in the structure of exports, as evidenced by the fact that the agricultural sector, showing stability during the last three years, accounted for almost $40 \%$ of the country's currency earnings (Jacenko, 2013).

Ukraine is still a world leader in production of 90-100 million tons of grain crops annually. The country is the third largest exporter of grain in the world (annual exports of 50-60 million tons).

By the end of April 2020, Ukraine had already exported about 50 million tons of grain, grain legumes (together with processed products) and flour (Official website State Stat. Serv. of Ukraine, 2021).

Agriculture remains a priority sector for the Ukrainian government, especially after signing the Association Agreement with the EU and implementation of the Deep and Comprehensive Free Trade Agreement with the EU. Since the date of signing the Association Agreement, the agricultural exports to the EU increased by more than one third (by 37\%, from 4.5 billion in 2013 to 6.1 billion in $2018+6.6$ billion in 11 months of 2019). Moreover, according to the data of monthly monitoring of agricultural trade by the European Commission, during the period from November 2018 to October 2019, Ukraine ranked third in the list of largest suppliers of agricultural products to EU countries with its exports in the amount of 7.3 billion EUR.

Since 2017, Ukraine has enjoyed the free trade area and managed to obtain additional preferential quotas for honey, grape juice, processed tomatoes, barley groats, oats, wheat, barley and corn.

At the end of 2019, the European Parliament also decided upon the overall increase of quotas for duty-free export of chicken from Ukraine up to 70 thousand tons per year till 2021. In 2019, the domestic exporters completely filled the quotas for honey (basic and additional quotas), sugar, barley groats and flour, processed starch, canned tomatoes, apple and grape juices, corn (basic and additional quotas), wheat, poultry, butter, processed cereals and starch (Agriculture in Ukraine, 2020).

The main exporters of Ukraine's agricultural products are large or integrated enterprises, including those incorporated by means of integration of companies involved in agricultural and related activities (Patyka, 2018). They are innovative enterprises, and it ensures a high level of productivity in the crop and livestock farming. The advanced facilities and technologies allow for the accumulation of financial and material resources, thus organizing the production process. The large and integrated enterprises are increasing the export volume which helps to improve logistics and reduce costs. 
Obtaining competitive advantages based on the price and experience economy also helps to minimize the influence of risks due to economy of sale. Therefore, the integration of businesses involved in foreign economic activities is becoming one of priorities to achieve competitiveness of domestic agricultural products in foreign markets.

It should be noted that the strategy of Ukrainian goods promotion in world markets must be moderately aggressive and sometimes aggressive. This strategy is to be chosen because the countries which are leaders in supplying certain goods or services are strengthening their position in most world markets, and this trend is becoming particularly stable and pronounced in agricultural markets (Fig. 3).

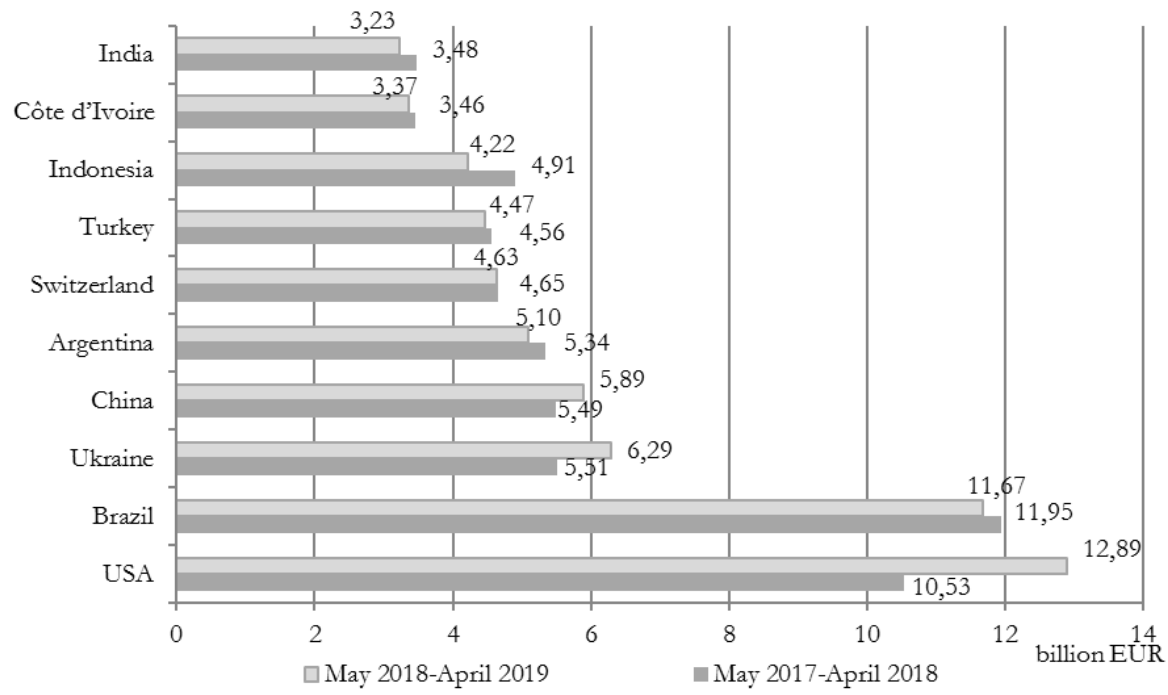

Fig. 3. Top exporters of agricultural products to the European Union (billion EUR).

The analysis of the economic situation in 2019 shows that the United States, Brazil, China, Ukraine, Argentina became the main exporters of agricultural products to the European Union, as their share in the world exports constituted $42 \%$. However, the export growth rate of leading agricultural exporters was not the highest in the world, which indicates that there is a potential for further development of the agricultural market of these countries. The production globalization has provided access to raw materials, equipment and many related services at international scale. Besides, labor and capital mobility has settled the problem of their shortage in many countries. Nowadays, we both have access to these factors and use them, and it makes them crucial for a competitive position. The identification of actual and potential advantages of the national economy and understanding of the global product market helps in planning comprehensive programs to increase the competitiveness of markets and goods and achieve a competitive advantage in the agricultural sector. Therefore, with due regard to the importance of agricultural exports in the economy, importance of sales at different stages of product export, analysis of competitive advantage concept and factors significant for this sector, we can define competitiveness as a set of institutions, policies and factors which determine the country's profits. 
Nowadays, the trade is influenced by national competitiveness, technological innovations resulting from stably improving competitiveness, diversity of needs and transformation of local markets into global ones. To gain a competitive advantage and be successful, the countries need to be more attentive to the wants and demands of markets (consumers). The authors of (Sukach, 2015) have calculated the index of Ukraine's relative agricultural export competitiveness in the global market using the product competitiveness assessment (Table 1).

Table 1. Index of Ukraine's relative export competitiveness in the global market

\begin{tabular}{|c|c|c|c|c|c|c|c|c|c|c|c|c|}
\hline \multirow[b]{2}{*}{ Product } & \multicolumn{3}{|c|}{2016} & \multicolumn{3}{|c|}{2017} & \multicolumn{4}{|c|}{2018} & \multicolumn{2}{|c|}{2019} \\
\hline & 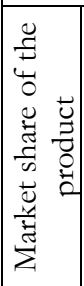 & 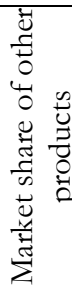 & 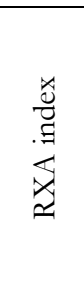 & 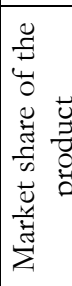 & 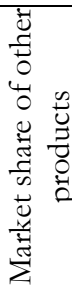 & 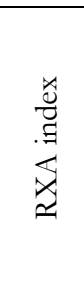 & 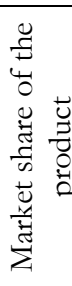 & 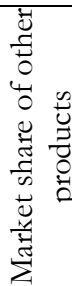 & 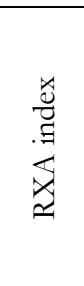 & 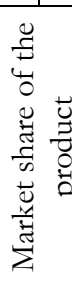 & 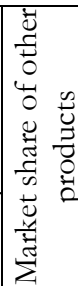 & 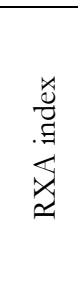 \\
\hline Sunflowe & 17,6 & 82,5 & 0,213 & 16,8 & 83,2 & 0,203 & 14,3 & 85,7 & 0,167 & 11,9 & 88,1 & 0,135 \\
\hline Corn & 12,6 & 87,4 & 0,144 & 11,7 & 88,3 & 0,132 & 12,2 & 87,8 & 0,139 & 15,7 & 84,3 & 0,187 \\
\hline Barley & 3,15 & 96,9 & 0,033 & 2,78 & 97,2 & 0,029 & 2,37 & 97,6 & 0,024 & 1,49 & 98,5 & 0,015 \\
\hline Wheat & 12,9 & 87,1 & 0,148 & 10,8 & 89,2 & 0,121 & 10,4 & 89,6 & 0,116 & 10,3 & 89,7 & 0,115 \\
\hline Soya beans & 4,67 & 95,3 & 0,049 & 4,14 & 95,9 & 0,043 & 2,88 & 97,1 & 0,03 & 3,36 & 96,6 & 0,035 \\
\hline Honey & 0,46 & 99,5 & 0,005 & 0,52 & 99,5 & 0,005 & 0,34 & 99,7 & 0,003 & 0,31 & 99,7 & 0,003 \\
\hline Sunflower ca & 3,44 & 96,6 & 0,036 & 3,08 & 96,9 & 0,032 & 3,06 & 96,9 & 0,032 & 3,51 & 96,5 & 0,036 \\
\hline Soybean oil & 0,53 & 99,5 & 0,005 & 0,49 & 99,5 & 0,005 & 0,53 & 99,5 & 0,005 & 0,67 & 99,3 & 0,007 \\
\hline
\end{tabular}

Based on the collected data, we conclude that the country does not have comparative competitive advantages in the export of products under study. However, as the country has a leading position among agricultural producers in the global market, we cannot categorically state that the domestic products lack competitiveness.

While the total exports are decreasing, the share of agricultural exports is growing. In recent years, the share of Ukraine's agricultural exports in its total exports has increased by $36.3 \%$. Yet, the agricultural exports mainly consist of raw materials, plant products in particular. In 2019, the agricultural sector of Ukraine (the processing industry included) generated approximately $18.5 \%$ of GDP. The crop farming accounting for $73 \%$ of total agricultural products dominates agriculture. The leading sub-sector is grain production. According to the statistics of the Food and Agriculture Organization of the United Nations, by 2020 the production of grain and soybeans will reach 70 million tons in Ukraine, and by 2024 it will reach 78 million tons (Official website of the UN, 2021). It is a significant crop yield growth, and many experts believe that Ukraine's overall grain production potential is 140 million tons. Oilseeds are the second most important subsector in the Ukrainian crop farming. Sunflower, soybean and rapeseed are the main oilseeds. Ukraine has turned sunflower oil production into a leading industry (Table 2). 
Table 2. Index of Ukraine's relative dependency on imports in the global market

\begin{tabular}{|c|c|c|c|c|c|c|c|c|c|c|c|c|}
\hline \multirow[b]{2}{*}{ Product } & \multicolumn{3}{|c|}{2016} & \multicolumn{3}{|c|}{2017} & \multicolumn{3}{|c|}{2018} & \multicolumn{3}{|c|}{2019} \\
\hline & 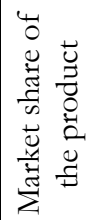 & 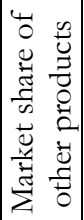 & 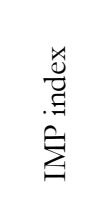 & 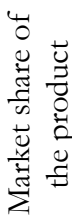 & 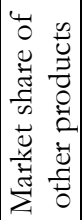 & 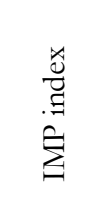 & 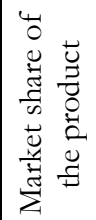 & 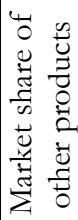 & 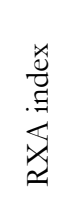 & 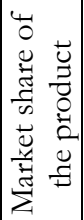 & 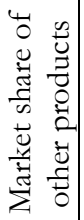 & 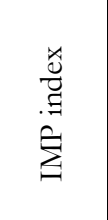 \\
\hline Sunflower oil & 0 & 100 & 0 & 0 & 100 & 0 & 0,0011 & 100 & 0 & 0,04 & 99,96 & 0,0004 \\
\hline Corn & 0,3213 & 99,68 & 0,0032 & 0,52 & 99,71 & 0,00517 & 0,2701 & 99,73 & 0,003 & 0,257 & 99,74 & 0,0026 \\
\hline Barley & 0 & 100 & 0 & 0,01 & 100 & 0,00008 & 0,0047 & 100 & 0 & 0,006 & 99,99 & 0,00006 \\
\hline Wheat & 0,0059 & 99,99 & 0,00006 & 0,01 & 99,99 & 0,00012 & 0,0053 & 99,99 & 0 & 0,019 & 99,98 & 0,00019 \\
\hline Soya beans & 0,0136 & 99,99 & 0,00014 & 0,02 & 99,99 & 0,00023 & 0,0073 & 99,99 & 0 & 0 & 100 & 0 \\
\hline Honey & 0 & 100 & 0 & 0 & 100 & 0 & 0,0001 & 100 & 0 & 0 & 100 & 0 \\
\hline Sunflower cake & 0,0163 & 99,98 & 0,00016 & 0,03 & 99,98 & 0,00029 & 0,0177 & 99,98 & 0 & 0,013 & 99,99 & 0,00014 \\
\hline Soybean oil & 0 & 100 & 0 & 0 & 100 & 0 & 0,0001 & 100 & 0 & 0 & 100 & 0 \\
\hline
\end{tabular}

According to the calculated data, we come to the conclusion that the country has a fairly low import dependency; it is practically absent, which is quite positive. The market share of some goods (sunflower oil, barley, honey, soybean oil) in overall imports is quite little and close to zero, but it does not mean that these products are not imported at all.

The importance of using both exports and imports to calculate competitiveness is becoming increasingly important as far as the intra-industry trade growth is concerned. The relative trade advantage index allows us to draw some general conclusions. This index can be both positive and negative because it reflects the presence or absence of competitive advantages; furthermore, it does not have a minimum or maximum limit, and it is a challenge for establishing the presence or absence of competitive advantages. Since the index is asymmetric, it is problematic to interpret its value. If the arithmetic mean is used, the distribution function from the probability density function is shifted to the right. This means that during the dynamic analysis of comparative advantages, the changes in sectors with the large values of relative trade advantage index will be exaggerated (Table 3).

Table 3. Index of Ukraine's relative trade advantages in the global market

\begin{tabular}{|l|c|c|c|c|}
\hline Product & 2016 & 2017 & 2018 & 2019 \\
\hline Sunflower oil & 0,213 & 0,203 & 0,167 & 0,134 \\
\hline Corn & 0,142 & 0,127 & 0,136 & 0,184 \\
\hline Barley & 0,033 & 0,028 & 0,024 & 0,015 \\
\hline Wheat & 0,148 & 0,121 & 0,116 & 0,114 \\
\hline Soya beans & 0,049 & 0,043 & 0,03 & 0,035 \\
\hline Honey & 0,005 & 0,005 & 0,003 & 0,003 \\
\hline Sunflower cake & 0,036 & 0,031 & 0,031 & 0,036 \\
\hline Soybean oil & 0,005 & 0,005 & 0,005 & 0,007 \\
\hline
\end{tabular}

According to the calculated indices of Ukraine's relative trade advantages in the global market, we can say on a positive value of this indicator, which means that certain Ukrainian products have relative competitive advantages in the foreign trade. 
The agricultural product competitiveness depends on a number of factors, namely: economic factors (basic economic and consumer properties of products); technical and technological factors (compliance with the standards and norms that determine the technical properties of products and regulate the processing technique); aesthetic factors (product appearance and its perception by consumers when being used); organizational factors (payment and delivery terms, dates, warranty and service, etc.).

One of the most recent discoveries of modern science is the strategic trade policy, implying the use of new economic conditions, including technological advancements, exceptional competition and performance improvement thanks to the efficient application of trade policy and its tools. This is due to the fact that global trade can make production factors mobile and ensure receiving the planned income and profits. The enterprise aims at transforming the established relative advantages into competitive advantages by reducing the cost of production and improving the quality of its products.

The sustainable competitive advantage deals with the functional status of enterprise, i. e. resources necessary to implement the strategy of creating values which are not easy to duplicate. To implement this strategy, the enterprise utilizes a scientifically sound approach to the use of its internal resources, thus getting a chance to have a significant market share. The potential investor considers the strategic importance of these resources. If the enterprise has patented procession techniques of unique efficiency, it can enjoy a competitive advantage. Similarly, the enterprise can maintain its competitive advantage over existing or new market participants.

Therefore, the countries using innovative technologies for growing high-yielding crops and animal breeds, efficient processing, storage and transportation systems, modern protection methods, fertilizers and science-based technical means, and not those with the most favorable natural, climatic and labor potential, become global trade leaders.

Conducting business in such a way ensures a high level of productivity and product quality at a relatively low cost, which makes it possible for enterprises to achieve a high level of competitiveness in the context of agricultural market globalization as far as price, quality and range of products are concerned.

According to the calculations, product innovations are becoming a determinative factor for agribusiness.

Since the agricultural product properties are relatively similar, it is difficult to characterize product innovations. This can be an innovative procedure or entering a new market. It can also be a new product or service, structure, manufacturing practice, or system of administration. Introducing innovations into business will ensure further growth of Ukraine's agricultural competitiveness in the global market. Besides, the time factor is important. Enterprises can be competitive if they begin to use capital resources and new development strategies earlier than their competitors.

When improving competitiveness, the choice and implementation of the enterprise's export strategy in the global market are essential. For example, it can be a direct exporting strategy. The advantage of direct exporting is that the producer has direct contact with the end users and retailers. So the producer can better know the requirements of foreign customers and adapt its product to the changing market needs. The exporter can quickly increase exports by means of intensive direct exporting in the market. One of the biggest advantages of direct exporting is a direct sales channel, which always avoids unnecessary 
intermediaries, thus offering a lower price to the end users. The exporter also closely investigates the foreign market and gains complete knowledge about its customers. When improving its product competitiveness in the market, the exporter builds the brand reputation and finally gets better at international marketing.

\section{Discussion of the Results of Analysis of Enterprise Competitiveness in the Agricultural Market in the Context of Globalization}

In recent years, the United States and Brazil have become world leaders among agricultural exporters (Fig. 3), their share of agricultural exports being $12 \%$ of total global exports in 2019. The key success factor of these agricultural producers is government assistance, creating conditions for the export market formation and producers' vigorous efforts to improve agricultural production technologies, formation of permanent markets with the same quality standards and search for innovative approaches to business activities. Ukraine, China and Argentina played an important role in growth of global agricultural exports, there share of agricultural exports being 5.5\% of total global exports in 20182019, respectively. These regions are also high volume importers of agricultural products, i. e. their exports and imports are relatively balanced.

The indices of Ukraine's relative export competitiveness (Table 1) in the global market have decreased over the period under study, which is definitely a negative trend. During this period, the index of relative export competitiveness of corn in the global market was the highest among the products under study, but it constantly fluctuated. In 2019, the index of relative export competitiveness increased by 0.043 points against 2016. During the same period, the index of relative export competitiveness of wheat gradually decreased. Thus, in 2019, the index of relative export competitiveness decreased by 0.033 against 2016. During the same period, the index of relative export competitiveness of barley was also high among other products under study, but this trend did not persist. In 2019, the index of relative export competitiveness increased by 0.018 points against 2016 . The index of relative export competitiveness of sunflower oil decreased by 0.078 points against 2016 . The indices of relative export competitiveness of soybeans, honey, sunflower meal and soybean oil were in general quite low and gradually decreased; it emphasizes the need to develop a new strategy in order to improve competitiveness of these products.

Future lines of research may include research and development of an efficient mechanism for enterprise competitiveness management in the agricultural market, based on progressive and efficient innovative development; research of the main aspects of enterprise competitiveness management; development of a concept of anti-crisis management of the enterprise's potential, as well as implementation of an efficient business strategy, which would ensure the creation of a mechanism to definitely achieve a high level of enterprise competitiveness.

\section{Conclusion}

The enterprise competitiveness is considered to be a multidimensional relative structure that includes a number of indicators jointly adapted for its measurement. In today's economy, it is the enterprises which become more competitive by means of 
continuous improvement and which can offer products of various types, more attractive and unique products that enjoy market success. The steady improvement of enterprise competitiveness is impacted by globalization activities, further distribution of technological standards and integration of national economies. The management theorists and practitioners do not fully agree on the definition of enterprise competitiveness. Enterprise competitiveness is characterized by dynamism, entrepreneurial attitude, ability to develop and implement modern technologies, administrative efficiency and production quality. The unique definition of competitive advantages in agriculture gives a further impetus to the improvement of competitiveness. The producers having rare resources, which are difficult to imitate and which have no available substitutes, have sustainable competitive advantages in the market.

The science-based methods of determining product competitiveness allow each producer to choose the economic direction and develop a strategy for achieving the business purpose and main objectives. In this research we studied the proposed methods of determining and assessing the level of agricultural product competitiveness, used the method of determining relative trade advantages, and it allowed us to assess the level of agricultural product competitiveness in the context of globalization. The calculated indices of relative trade advantages of domestic products have a positive value, which indicates that the products under study have competitive advantages. Furthermore, Ukraine has become one of the world's leading exporters of grain and forage crops. Large and integrated enterprises remain the main exporters of agricultural products in Ukraine. The index of Ukraine's relative dependency on imports from the global market reveals that Ukraine does not have import dependency.

Based on the general results of the research, we can say that the domestic producers have competitive advantages as to sell agricultural products, but the level of competitiveness is constantly fluctuating and is quite unstable. In order to improve competitiveness and achieve stable competitive advantages, it has been proposed as follows. Innovative technologies and science-based businesses are essential. The implementation of the strategy aimed at creating values quite unique on grounds of certain parameters will enable to fill a specific market niche and increase a market share. Using the direct exporting policy, the exporter exercises effective control over its product, avoiding unnecessary intermediaries; quality products offered at a relatively lower price improve the producer's standing in foreign markets. Taking into account the globalization processes and increasing competition, the enterprises may suffer losses and be unable to compete on a global stage if they do not pay attention to opportunities and risks in the course of their production process.

\section{References}

Agriculture in Ukraine. DLF ATTORNEYS-AT-LAW, 25 травень, 2020. URL: https://dlf.ua/ua/silskegospodarstvo-v-ukrayini/\#9 (Accessed 15.04.2021).

Boghomolova, K.S. (2019). Sutnistj ta faktory formuvannja konkurentospromozhnosti aghrarnykh pidpryjemstv. [The essence and factors of the formation of the competitiveness of agricultural enterprises]. Bulletin of the Kharkiv National Technical University of Agriculture named after Petro Vasilenko. Issue 200. pp. 118-128. 
Bojko, V., Bojko, L. (2019). Suchasni pidkhody do vyznachennja ponjattja «konkurentospromozhnistj aghrarnykh pidpryjemstv». [Modern approaches to defining the concept of "competitiveness of agricultural enterprises"]. Financial space. № 3 (35). pp. 23-31.

Brych, V.Ja., Okhota, V.I. (2019). Mizhnarodna konkurentospromozhnistj krajin v umovakh ghlobalizaciji: monoghrafija. [International competitiveness of countries in the context of globalization: a monograph]. Ternopil: TNEU, 212 p. (in Ukrainian).

Da Huo, Yan Chen, Ken Hung, Zening Song, Jialin Guan \& An Ji (2020). Diamond model and the export competitiveness of the agriculture industry from emerging markets: an exploratory vision based on a spatial effect study using a genetic algorithm. Economic Research-Ekonomska Istraživanja. Vol. 33, No. 1, pp. 2427-244. URL: https://doi.org/10.1080/1331677X.2019.1679212. (Accessed 09.04.2021).

Dughijenko, N.O. Symonenko, O.O. (2015). Konkurentospromozhnistj APK Ukrajiny v umovakh jevrointeghraciji. [Competitiveness of the agro-industrial complex of Ukraine in the conditions of European integration]. Global and national economic problems. Issue 5. pp. 81-84.

Ghranovsjka, V.Gh. (2017). Instytucijnyj mekhanizm zabezpechennja konkurentospromozhnosti aghrarnykh pidpryjemstv. [Institutional mechanism for ensuring the competitiveness of agricultural enterprises]. Bulletin of the Sumy National Agrarian University. Vol. 4. pp. 128-133.

Ian, M., Sheldon (2017). The competitiveness of agricultural product and input markets: a review and synthesis of recent research. Journal of Agricultural and Applied Economics. Vol.49. Issue 1. pp. 1-44.

Ivanova, M., Varyanichenko, O., Sannikova, S., \& Faizova, S. (2018). Assessment of the competitiveness of enterprises. Economic Annals-XXI. 173(9-10). pp. 26-31.

Jacenko, O.M. (2013). Konkurentospromozhnistj ghaluzej siljsjkogho ghospodarstva v umovakh ghlobalizaciji rynku prodovoljstva. [Competitiveness of agricultural sectors in the context of the globalization of the food marke]. Economics of the agro-industrial complex. № 1, pp. 31-38.

Kamila, Zelga (2017). The importance of competition and enterprise competitiveness. World Scientific News. № 72. pp. 301-306.

Kasych, A.O., Ghlushhenko, D.O. (2016). Teoretychni ta praktychni aspekty upravlinnja konkurentospromozhnistju pidpryjemstva. [Theoretical and practical aspects of enterprise competitiveness management]. Economy and State. № 11. pp. 65-70.

Krjuchkova, Zh.V. (2016). Metodychni pidkhody do vyznachennja rivnja konkurentospromozhnosti aghrarnykh pidpryjemstv. [Methodological approaches to determining the level of competitiveness of agricultural enterprises]. Agroworld. № 12. pp. 41-46.

Kuzmenko, O. (2018). Directions of Increase of Competitiveness of the Enterprise. International Journal of Innovative Technologies in Economy. 6(18). Vol. 2. pp. 54-58.

Kvasha, S.M., Gholomsha, N.E. (2006). Konkurentospromozhnistj ukrajinsjkoji siljsjkoghospodarsjkoji produkciji na svitovomu arghrarnomu rynku. [Competitiveness of Ukrainian agricultural products in the world agricultural market]. Economy of the agro-industrial complex. № 5. pp. 99-104.

Kyrychenko, O.M., Mighdaljsjkyj, A.V. (2017). Metody ocinjuvannja konkurentospromozhnosti pidpryjemstva. [Methods for assessing the competitiveness of an enterprise]. Efficient economy, [Online]. № 2. URL: http:/ /www.economy.nayka.com.ua/?op=1\&z=5428 (Accessed 07.04.2021).

Leśniewski, M.A. (2018). Competitiveness as a measure of organization development - the theoretical study. Scientific notes of the National University "Ostroh Academy". NaUAA Publishing House. № 9(37). pp. 5964.

Ljashevsjka, V.I., Skvira, I.O., Bojko, Ju.A. (2018). Konkurentospromozhnistj pidpryjemstv aghrarnogho sektoru na zovnishnjomu rynku. [Competitiveness of enterprises in the agricultural sector in the foreign market]. Black. Sea Economic Studios. Issue. 28-1. pp. 31-34.

Official website FAOSTAT. URL: http://faostat.fao.org/site/339/default.aspx. (Accessed 15.04.2021).

Official website of the State Statistics Service of Ukraine. URL: http://www.ukrstat.gov.ua. (Accessed 15.04.2021).

Official website of the United Nations. URL: https://www.un.org/ru/sections/resources-differentaudiences/(Accessed 15.04.2021).

Pakhucha, E.V. (2018). Vplyv vnutrishnikh i zovnishnikh faktoriv na konkurentospromozhnistj siljsjkoghospodarsjkykh pidpryjemstv. [The influence of internal and external factors on the competitiveness of agricultural enterprises]. Effective Economy, [Online]. №7. URL:http://www.economy.nayka.com.ua/pdf/7_2018/43.ppd (Accessed 05.04.2021) 
Pakhucha, E.V. (2020). Zastosuvannja instrumentiv marketynghovykh komunikacij u pidvyshhenni konkurentospromozhnosti pidpryjemstv. [Application of marketing communications tools in increasing the competitiveness of enterprises]. Agroworld. №19-20. pp. 82-89.

Patyka, N. (2018). Priorytety zabezpechennja konkurentospromozhnosti siljsjkogho ghospodarstva Ukrajiny na svitovykh rynkakh. [Priorities of ensuring the competitiveness of Ukraine's agriculture on world markets]. Agricultural and Resource Economics: International Scientific E-Journal. Vol. 4, No. 4. C. 130-145.

Radev, Stoyan, K., Pavliuk, S., Derhaliuk, M., Sokolova, L. \& Portna, O. (2020). Resource Strategy for Enterprise Management as a Tool to Ensure its Competitiveness. Academy of Strategic Management Journal. Vol. 19. Issue. 4, URL: https://www.abacademies.org/articles/resource-strategy-forenterprise-management-as-a-tool-to-ensure-its-competitiveness-9360.html (Accessed 01.04.2021).

Shevchenko, V., Kokuytseva, T. \& Ovchinnikova, O. (2019). Competitiveness of the Enterprises of the Eurasian Economic Union: Assessment Methodology. Revista ESPACIOS. Vol. 40. Issue 37. pp. 1522.

Sieradzka, K., Luft, R. (2015). Theoretical aspects of enterprise competitiveness. Central European review of economics \& finance. Vol. 10. No. 4, pp. 133-141.

Sievidova, Iryna (2018). Formuvannja strateghiji na osnovi naukovykh doslidzhenj z vykorystannjam instrumentariju nekooperatyvnoji teoriji ighor. [Formation of research-based strategies for the use of instruments of non-cooperative game theory]. Effective Economy, [Online]. Vol. 3. URL: http://www.economy.nayka.com.ua/?op=1\&z=6282 (Accessed 04 Apr 2021).

Skrynkovskyy, R.M. (2015). Diaghnostyka konkurentospromozhnosti produkciji pidpryjemstva. [Diagnostics of the competitiveness of the company's products]. Economic problems. № 4. pp. 240-246.

Skrynkovskyy, R., Shpak, O., Protsiuk, T. \& Noga, I. (2018). Formation of the Toolkit for Graphical Assessment of Enterprise Competitiveness. Path of Science: International Electronic Scientific Journal. Vol 4, No 1. pp. 1014-1021.

Stawasz, E. (2019). Factors that shape the competitiveness of small innovative companies operating in international markets with a particular focus on business advice. Journal of Entrepreneurship, Management and Innovation. Vol. 15(1). pp. 61-82.

Stepasyuk, L., Titenko, Z. (2020). Competitiveness of agricultural products of ukraine in the foreign market. Modern management review. Vol.15. p. 69-77.

Sukach, Ju.V. (2015). Metodychni zacady ocinky mizhnarodnoji konkurentocpromozhnocti zerna ta faktoriv vplyvu na neji. [Methodological tasks of assessing the international competitiveness of grain of factors of influence on it]. Global and national problems of the economy. Issue. 7. pp. 72-75.

Yamova, O.V., Maramygin, M.S., Sharova, I.V., Nesterenko, J.N., Sobina, N.V. (2018). Integral Valuation of an Enterprise's Competitiveness in the Industrial Economy. European Research Studies Journal. Vol. 11. Special Issue 2, pp. 777-787.

Zakrevsjka, L.M. (2004). Ocinka konkurentospromozhnosti pidpryjemstv kondytersjkoji promyslovosti. [Assessment of the competitiveness of enterprises in the confectionery industry]. Economics: problems of theory and practice: Sat. sciences. works of DNU. Issue 195.Vol. 2. C. 503-514.

Zbarsjkyj, V.K., Misevych, M.A. (2009). Konkurentospromozhnistj vysokotovarnykh siljsjkoghospodarsjkykh pidpryjemstv. [Competitiveness of high-value agricultural enterprises]. K.: NSC IAE. 310 p. (In Ukrainian).

Zosj-Kior, M.V., Ghermanenko, O.M., Sobakar, D.T. (2018). Suchasni aspekty upravlinnja konkurentospromozhnistju pidpryjemstva. [Modern aspects of enterprise competitiveness management]. Priazovsky Economic Bulletin. Vol. 6(11). pp. 174-180. 